\title{
TOWARD A CRITICAL AND COMPARATIVE ANTHROPOLOGY OF DISABILITY
}

\author{
Absent Presence and Exemplary Personhood
}

Joshua Reno, Kaitlyn Hart, Amy Mendelson, and Felicia Molzon

\begin{abstract}
This article places anthropology in dialogue with critical disability studies (CDS) in order to reassess historical and emerging ethnographic readings of difference. We argue that one unintended consequence of a lack of attention to disability in anthropology, generally, has been an impoverished conception of personhood and power. Building on insights from CDS and the ethnographic literature, we show how non-normative bodies and minds can play a critical role in relationships with non-human others and exemplary persons. Looking beyond hegemonic and secular ideas of disability as a form of misfortune or lack not only offers alternatives for being with disability, in keeping with the aims of CDS, but also shows new directions for comparative discussions of power and difference.
\end{abstract}

Keywords: comparison, difference, disability, ethnographic record, personhood, power

"Given the centrality of diversity to our epistemology," Faye Ginsburg and Rayna Rapp (2013: 55) write, “why has the subject of disability not been a key topic for our discipline?" Their sentiment has been reiterated (Ginsburg and Rapp 2020) and shared by scholars going back some 70 years-from Hanks and Hanks (1948), Edgerton (1967, 1970), Ablon (1984, 1988, 1999), Ingstad and Whyte (1995), to Klotz (2004), Shuttleworth and Kasnitz (2004), and Reid-Cunningham (2009) - all of whom have advocated for an anthropology of disability in various ways. Anthropologists studying disability have always been relatively few in number, usually a subset of those in medical and applied anthropology, which Ginsburg and Rapp point out. Yet, as we will argue, a critical and 
comparative analysis of disability helps anthropologists see past and present evidence in new ways, in dialogue with approaches in disability studies. Such a dialogue offers insights that are mutually beneficial to these approaches as they apply to the anthropological record. In the first part we examine what critical disability studies can contribute to anthropological analysis; in the second, we consider how a comparative anthropology can contribute alternative ways of imagining personhood and power as opposed to the dominantly secular perspectives currently found in the Euro-American-dominated field of disability studies.

Many possible definitions of disability have existed throughout history. One may perceive disability not only as an actual condition a person may experience, but as a variation from some imagined (and likely impossible) ideal-the 'normate' (Garland-Thomson 1997). In this sense, disability helps to shape the thoughts and actions of anyone who worries about being different, aging, or suffering misfortune, which is to say practically everyone. In critical disability studies, the task is not only to empower people with disabilities, but to challenge (or 'crip') existing systems of ableism that afflict disabled and ablebodied alike. Specifically in 'crip theory', as in 'queer theory' (see Kafer 2013; McRuer 2006, 2018), the aim is to challenge compulsory normativity, which maintains social relations and life courses in contradistinction to disability. This differs from the suggestion that disability is socially constructed, as in the 'social model' of disability popularized in England in the 1990s (see Shakespeare 2017). In this interpretation, people with disabilities are an invented and oppressed minority; in response, important and hard-fought policies emerged in the latter half of the twentieth century to eliminate barriers to inclusion and success, the classic example being the building of wheelchair ramps in more public settings.

Crip theorists do not dispute the benefits of the social model and related struggles, but insist that processes of compulsory hypernormativity mean that any attempt to 'include' disabled people, voices, and experiences in society disavows how disability is already implicated within taken-for-granted assumptions and systemic orders in unacknowledged ways (Titchkosky 2011). As Margrit Shildrick (2001: 71) puts it: "We are all implicated on an everyday level in a process of discursive othering that serves to establish and perpetuate standards of normativity." Compulsory able-bodiedness and able-mindedness, as examples of systemic ableism, assume "able-bodied identities, able-bodied perspectives are preferable and what we all, collectively, are aiming for" (McRuer 2006: 9). Within such ableist systems, disabled bodies and minds become undesirable possibilities of being ("I'd rather die than be like that") for themselves or others ("We don't care about the baby's gender, we just want it to be healthy").

Disability studies have benefited from a 'global turn' in the last decade (Erevelles 2011; McRuer 2018). According to the inter-sectional approach of 
some indigenous and disabled activists and scholars (Hutcheon and Lashewicz 2020), contemporary forms of ableism are also mutually implicated in projects of colonialism. Moreover, the global disability movement has been criticized for being too closely tied to hegemonic representations of disability originating primarily from the Global North (see Connell 2011; Grech 2015; Jaffee 2016). This also exposes some possible limitations in contemporary disability studies, no matter how purportedly 'global' its reach. Although continually seeking new and radical ways of imagining and being with disability, crip theory primarily tends to remain confined to secular conceptions of disability as the biomedical condition and experience of an individual. While critical disability theorists like Kafer (2013) importantly cast disability as thoroughly relational, those relations are only ever to purportedly physical, co-present beings and forces in this world. Our conviction is that anthropology might make up for this lack of appreciation of cultural difference in disability studies and activism, at least in some of their most widespread and hegemonic forms, by opening up new ways of looking at social relating and power.

Applying insights from the interdisciplinary field of critical disability studies to the ethnographic record means recognizing first that ableist representations, actions, and systems are potentially implicated across all domains of social life. The first argument of this article examines ableist tendencies in anthropology. Not only have anthropologists historically failed to fully commit to the study of disability, we argue, but they have actively excluded disabled persons and experiences from consideration. To support this claim, we use a selective example from one well-known ethnographic case study, the Kwakwaka'wakw of the Pacific Northwest. Our article shows that the topic of disability was excluded-intentionally or unintentionally-from this well-known and heavily analyzed example. Moreover, we present new ways of evaluating this now archetypal ethnographic setting.

This kind of alternative reading of old ethnographic material contributes to broader challenges to compulsory able-bodiedness and able-mindedness, both of which reach far beyond yet are partly shaped by scholarly practice. At the same time, this demonstrates the value that anthropology has for critical disability studies, as we argue in the second half of our article. Building an archive of disability in the way we have proposed complicates the ordinary vision of the ethnographic and historical 'record' as a singular, unchanging corpus or collection. We seek to highlight how this image of the ethnographic record is premised on hegemonic, ableist ways of reading and reanalyzing ostensibly independent and isolated ethno-historical facts. ${ }^{1}$ Specifically, we argue that alternative conceptions of disability, placed in cultural context, challenge the tendency to reduce non-normative difference to lack or loss, to sickness, suffering, or inauspiciousness. We focus especially on examples that, seen through a comparative disability lens, show non-normative persons 
playing a central role in relationships with 'exemplary persons' that take on greater moral weight and cosmological consequence (Humphrey 2007). If conceptions about exemplary persons are implicated in thinking about non-normative enfleshment, then this demands that we rethink the implicitly secular scales of personhood and power that typically structure disability scholarship and activism, in the same way as they do global queer scholarship and activism (Klinken 2019).

Having evaluated what critical disability studies can contribute to comparative anthropology and vice versa, we conclude by advocating for a broadened conception of non-normative bodies and behaviors that remains open to unanticipated possibilities of disability and exemplary personhood. This approach, we suggest, advances an anthropology of personhood and power that is more appropriate for an unequal world indelibly shaped by colonialism as well as ableism.

\section{The Absent Presence of Disability in the Ethnographic Record}

In this first section, we develop ethnographic examples from a relatively welltrodden setting. We deliberately chose the ethnography that Franz Boas and George Hunt (1921) completed in Fort Rupert, in the Pacific Northwest, because of its broad familiarity with readers of anthropology and its direct relationship to disabled subjects through salmon cosmologies. The logic behind our choice suggests that far more examples likely exist where the literature does not examine the presence of disability as closely. In other words, the 'classic' status of this work means that it provides better evidence for long-standing and systematic exclusion of disability (here in the form of 'cripples') as a topic within anthropology. Looking backward, in this way the work of Boas and Hunt is useful not simply because it is a well-known field study, but because it has been dissected over and over again for a century and therefore provides a unique test case for systematic exclusion (which, as an absence, is a hard thing to empirically demonstrate).

Aspiring and committed anthropologists routinely learn, discuss, write, and teach about Boas and Hunt's research. This led to disciplinary interest in the famed institution of the potlatch and, beyond that, to theories of the gift, value, and exchange that are still influential today (Graeber 2001). And yet, despite sustained analysis and reanalysis of the Fort Rupert material in the intervening time (Masco 1996), there has been little consideration of the relevance of non-normative bodies as belonging to the salmon. In this section, we revisit the much-discussed material on people of the Northwest, whom we call Kwakwaka'wakw, and those of Fort Rupert, whom we call Kwakiutl. This distinction maintains that of the great-granddaughter of George Hunt, Gloria Cranmer Webster (1991). As Masco (1996: 839) makes clear, with this distinction 
Webster "reintroduces her people to the world as postcolonial subjects ... [as] a mirage, the invention of a colonizing white society." Webster's alternative nomenclature, and the history-telling it involves, is arguably in keeping with Native American strategies of active survivance (Vizenor 1994). Retreading this ethnographic evidence is also, albeit in a different sense, partaking of alternative history-telling that calls into question the supposedly neutral construction of the ethnographic record: specifically, if Webster helps colonized Kwakwaka'wakw to reappear in ethnographic materials, we argue the same can be done for colonized disabilities.

There is, in fact, a section titled “Cripples" in Boas and Hunt's (1921: 696697) Ethnology of the Kwakiutl. ${ }^{2}$ Although brief, it reveals significant and unexamined conceptions about non-normative bodies and salmon:

When a woman gives birth to a one-eyed child, then all men say that it belongs to the Salmon. When a woman gave birth to a girl with a red spot like a strawberry on the forehead, here at Fort Rupert, it was said that it belonged to the Salmon; and a Koskimo woman gave birth to a boy whose right leg was bent, who belonged to the Salmon; and ... a woman, gave birth to a child who was white on one side of the face, and he also belonged to the Salmon; and ... a Koskimo woman, gave birth to a boy with a scar on the face; and also those who have scars on the body and who lack a finger,-all these about whom I am talking are said to belong to the Salmon. I have seen all this, when the people of all the tribes follow the rules that they have for the twin-children, and their parents also observe the taboos that belong to twin-children.

Understanding the passage on 'cripples' relies, as Hunt's interlocutor makes clear, on knowledge about care for twin children among Fort Rupert Kwakiutl and for Kwakwaka'wakw more broadly. The taboos that belong to twin children are outlined in far more detail in earlier passages by Hunt and Boas and have been discussed in depth by later scholars. Twins may not fit with Western notions of disability and may seem out of place in connection with 'cripples', but the presence of twins is directly associated with other non-normative bodily 'deformities' among the Semang (Schebesta and Schütze 1954), the Yuchi (Speck [1909] 2004), and the Pawnee (Dorsey et al. 1940), most often as something that will happen if certain taboos are not followed. At Fort Rupert, Boas and Hunt write, twins could undergo distinct naming practices and alternative upbringing and could receive designated ritual roles later in life. The reason for these additional rules is that twin children may transform into salmon if one is not careful. Even more importantly, they may eventually gain the ability to control fish and the weather if they are entrained correctly.

This connection between twins and, as the above passage confirms, 'cripples' has potentially profound implications. As commentators on Ethnology of 
the Kwakiutl have since noted, the bountiful fish of the Pacific Northwest are believed to have dramatically shaped social life in the Pacific Northwest to the point that subsistence was about far more than survival, making their lives fundamental in comparative discussions of value (see Graeber 2001). The chiefly practice of organizing potlatch owed itself to this abundance and its redistribution. One debate has been the extent to which these practices can be reduced to environmental circumstances or competitions of a purely economic sort around debt relations and hierarchy. According to Graeber, Kwakwaka'wakw "were a group of people who really did devote a huge proportion of their time and creative energy to the gathering of food and to related material production, not out of necessity, but because that's what they considered really important" (ibid.: 189). If abundant fish were a part of this break from necessity, and only twins and 'cripples' were raised to be close to and even control said fish, then truly understanding value relations among Kwakwaka'wakw (as anthropologists have seemed intent on doing over the last century) would seem to necessitate taking non-normative bodies seriously.

At the same time, it is important to note that ideas in both regions have changed since this original ethnography. For instance, there is no mention of twin-salmon connections in the autobiography of Kwakwaka'wakw fisherman, chief, and activist James Sewid (1971), despite the fact that he raises twin daughters. Moreover, there is no reason to assume that this analogical conception of 'cripples' being connected symbolically, ritually, and ontologically to salmon was always avowed or practiced by everyone all the time, not even at Fort Rupert where it was observed by Hunt and Boas (see Cepek 2016). Even so, the debate on the ontology of non-normative bodies can occur only if it is regarded as worth considering, which it had not been previously. While there may be many possible reasons for the exclusion of 'cripples' from subsequent considerations of Hunt and Boas's research, the fact of this exclusion is undeniable. In his introduction to the biography of Kwakwaka'wakw Chief Charles Nowell, Clellan Ford ([1941] 1968: 31) mentions the special and supernatural entraining of twins, but his only mention of additional children born physically different is that "badly deformed" infants were "destroyed at birth and buried in secret." Helen Codere (1966) provides a selective overview of Boas and Hunt's copious work that includes much of the discussion of twins, but nothing at all about cripples. In an important subsequent discussion of Hunt and Boas's ethnographic material, Stanley Walens (1981) describes twins as symbolically and iconically salmon-like (salmon have multiple births), and he also gives detailed information about their place among Kwakwaka'wakw, drawing extensively on Boas and Hunt (1921). Nothing is mentioned about 'cripples'.

Two key ideas emerge in our analysis of the selected ethnographic literature. First, even when disabled people are relevant to a given cultural situation, one that is repeatedly reanalyzed and made meaningful in new ways like the 
Kwakwaka'wakw potlatch, that is no guarantee that disabled people will be included as central or important to the matter at hand. It is therefore necessary to consciously attend, as disability theorists have been arguing for decades, to the presence, absence, and 'absenting' of disabled bodies and minds. The second point is that there are very different ways of categorizing and 'mattering' disability that challenge existing conceptions of human difference. These existing theories tend to fall back on an implicitly secular ontology such that relations with exemplary persons (e.g., people who belong to the Salmon) are of no account.

We will return to the issue of exemplary persons and social relations below. First, we submit that the absenting of disability takes two forms. One is its straightforward exclusion from reading and reanalysis of ethnographic material, as with the Ethnology of the Kwakiutl. An even more common example comes in the form of a tendency to miss the virtual presence of disability as a source of social control and discipline, as described in the disability studies literature. There are countless examples in existing ethnographic literature of normative rules and interpersonal demands that are articulated in reference to a possible disabled outcome (e.g., avoid this taboo or blindness, lameness, infertility, muteness will follow). Yet authors often overlook how disability facilitates or rationalizes said rules. For instance, Boas (1932: 200) would later write about the Fort Rupert Kwakiutl:

When a child is born with a defect ... the parents must find out what taboo they have broken. When a new-born child has warts like strawberries the parents have broken a strawberry taboo ... A young man married a Koskimo woman. He went hunting while his wife was pregnant. Although he had been warned not to do so, he clubbed a sealion, and its eyes dropped out of the head. When the baby was born there were no bones in the skull and the eyes hung out (... made unfortunate by the clubbed sealion.)

Not all societies would think to relate twins, 'cripples', and salmon with 'defects' in infants and strawberries or sea lions, but all societies arguably encounter and make sense of people and phenomena that violate normative categories (Douglas 1966). As Mitchell and Snyder (1997: 4) conclude, certain hegemonic notions of disability evoke some kind of naturalized "violation of expectations" about how bodies and minds grow and change: "The ill or the aged participate in a natural cycle of biological processes and breakdowns, but people with disabilities possess a biology that does not conform to even the most radical operations of normalization." There is nothing new about this from an anthropological perspective per se, yet normalizing practices and representations are rarely explicitly conceptualized in terms of its implications for disability, which cuts short more sustained dialogue between comparative anthropology and disability studies. Importantly, such violations are not just something that happens 
but something that people know and imagine can happen. What this means is that the everyday lives, values, and institutions of people who are ostensibly neurotypical and able-bodied are also shaped by the expectation, anticipation, and imagination of disability as a virtual possibility. By implication, disability is key to what counts as a person-anywhere and everywhere.

The virtuality of disability as a form of social discipline and domination is also easy to miss if disability is assumed to be purely medical and individual, rather than political and relational. One need never actually be or know someone autistic, blind, deaf, lame, or dumb to recognize that rhetorical appropriations of these terms in abusive speech virtually mark disability as weakness and deficit. The use of disability in ordinary speech is one obvious way in which ideologies of compulsory able-bodiedness can potentially shape anyone's capacity for engagement with social systems and how ideas of personhood are defined by them, but it can just as easily be used to valorize non-normative bodies and minds as special, unique, and empowered in the right circumstance. Referencing the financial infrastructure supported by diagnoses of autism, Grinker (2020: S56) asserts that "the autistic person becomes increasingly defined in ... terms of capital" as in depictions of neurodiversity as an advantage.

We acknowledge the polyvalence of disability for multiple domains of human existence, refusing to rely on simple epistemological divides between, for instance, the individual and the social, the medical and the cosmological. Following other scholars, we consider disability to be many things, including a debilitating structuring condition and also, as the case of the Kwakwaka'wakw shows, a possible resource or asset, sometimes manifesting as a literal form of cosmological power like control over the local food supply.

\section{Relating to Exemplary Persons and Comparative Disability}

In this section we consider a literature that is very different in its focus and therefore tends not to be taken up in discussions of disability despite the fact that it, too, is concerned with relatedness, power, and non-normative bodies. One of the most common associations in the ethnographic record with disability in its various forms, hiding in plain sight as either debilitating sickness and misfortune or acute impairment, is something that could happen if a law, rule, or prohibition is not heeded. In these examples, relations with exemplary persons-witches, gods, ghosts, spirit guardians, or similar other-than-human beings-are normally involved as the source of the rule and/or punishment. We call these persons 'exemplary' after Humphrey (2007) because it avoids many otherwise problematic terms (metaphysical, supernatural) that tend to reinforce a more or less secular ontological divide between this world and otherworldly beings and forces. ${ }^{3}$ Saying that these are 'exemplary persons' 
also works, Humphrey argues, to steer attention toward social relationships and away from whatever explicit 'rules' exist about how to behave. After all, placing analytic focus on the cultural etiology of disability-for example, this child ended up disabled because a husband went hunting while a wife was pregnant-might be the most common source for information about disabled bodies and minds in the ethnographic record. However, risks take for granted "the givenness of social structures and inherited practices" (ibid.: 27-28; see also Cepek 2016) as if they were unchanging and always enacted the same way in actual life. An emphasis on exemplars, by contrast, makes moral life and social control a matter of ordinary and extraordinary interpersonal relations and identifications (see also Laidlaw 2013; Robbins 2015). Importantly, for our purposes, while exemplars might represent hyper-normal individuals, in many cases they include persons who possess exceptional bodies and capacities.

It is helpful to think cross-culturally about exemplary persons with respect to disability, to avoid the secular presumptions that privilege biomedical interpretations of non-normative bodies and minds. Such conceptions of disability are hegemonic in rights activism and certainly in critical theory, where it goes without saying that a determination about whether a person is or is not disabled is a medical matter that is formally separate, in principle, from social relations with other-than-human or exemplary persons. Yet for many people around the world, it would be impossible to talk about disability without also taking into account relationships with exemplary persons of different kinds who might have caused the disability, who might dictate that a person should be treated differently (not necessarily better or worse) because of a disability, whose avatars or spokespersons might possess a disability that marks them as a vessel for exemplary persons to appear in the flesh, and so on. It would not be an exaggeration to say that these possibilities have been all but completely ignored in critical disability theory. This is similar to queer theory, as discussed by Adriaan van Klinken (2019), insofar as both have been shaped by secular presuppositions that cast 'religion' first as something whose influence has declined over time, through the disenchantment of the world, and second as primarily a source of ignorance, stigmatization, and oppression whenever it is present.

In most histories of disability, the tendency is to emphasize 'pre-modern' beliefs that highlight the perniciousness of tradition (see, e.g., Stiker 1999: 40; Woodill 1994). This secular bias is problematic in general, but Klinken (2019) argues with respect to queerness that it is especially so in many post-colonial African contexts, given the importance of religion in social and moral life. Black and indigenous people of color, whether or not they are part of the African diaspora, are continually relegated to what Engelke (2015: 87) calls the "time ago" of Europe's past, and secular discourse around what is termed 'religion' helps to maintain this image. This is important to challenge since it tends to promote colonial readings of disability in the present. As Klinken suggests, the benefit 
of seeing power and personhood in a post-secular way is that it challenges the reification of colonial distinctions between modern and non-modern, Western and non-Western, metaphysical and pre-modern worldviews. With disability, this would allow for cross-cultural examples involving exemplary persons who come to the fore as connected to unique disability worlds (see Devlieger et al. 2016; Ginsburg and Rapp 2020).

The problem with a tacit, secular perspective about disabled empowerment is that it disavows the (arguably, globally widespread) perspective that human actions, such as speech, emerge "through a differential, distributed, or divinely mediated process that involves multiple worldly and divine actors" (Friedner 2018: 660). Agency is not circumscribed by tradition or rules; rather, it is made possible in relation to exemplary others with whom people must negotiate and engage practically. In Bengal, religious values like renunciation and attachment "were experienced and pursued by Mangaldihi villagers as fundamentally varied, as coexisting and creating quandaries," writes Lamb (2000: 141). Similarly, the Tswana women Livingston (2005: 149) writes about were "armed with potentially healing prayers" perpetuating "women's historical roles in harnessing spiritual power to collective moral projects." If it is important to recognize how debility can lead to capacities for the transformation of one's own circumstances, then social relations are often a critical component.

And what is true for debility, as Livingston characterizes it, also works for cases of seemingly 'acute' disability. Consider the example of blindness among the Iban of Malaysia, for whom this condition has been linked to access to the spirit world and successful shamanism (Graham 1987; Jensen 1974). It was believed that a blind manang (shaman) had easier access to his spirit, "his contact, his guide, and helper in the spirit world" (Jensen 1974: 144). Yet Humphrey makes it clear that whoever counts as exemplars can change over time, as can the status that came with the gift of blindness. Torrance (1994: 148) states that whereas in the last century manangs "ranked second to village chiefs, and might be chiefs themselves," in recent years "their social standing is more equivocal. Most suffer from a physical handicap such as blindness and are stigmatized as failures in terms of normal Iban values. Skepticism toward them is common, yet the most prestigious manangs are highly respected members of the community." Whether a spiritually exemplary condition or a purely debilitating one, or both at once, disability is worth grasping in context as it emerges in depth precisely to the degree that it can instigate moral and cosmic debate for social actors.

Considering relations with exemplary persons provides one avenue by which debility and disability deviate from typical, often secular disability or minority rights frameworks. Yet this has gone undeveloped, both in critical disability studies and the more recent anthropology of debility and disability and in the anthropology of virtue ethics and social relations beyond the human, strictly 
speaking. This is partly due to the failure to develop a critical and comparative anthropology of disability in the first place. Another reason for this tendency is arguably rooted in an enduring association of disability with misfortune, suffering, and lack (Garland-Thomson 1997). While valuable, these critical readings of debility tend to be tacitly reliant on secular assumptions of power and personhood, where capacity is merely corporeal and never cosmological.

If, for instance, this world is not all there is, but is intertwined with another world or worlds, another being or beings, then it becomes less obvious what real, transformative change consists in. This would provide one possible source for a more in-depth consideration of what it is to undergo debilitation in a way that one's marginalized status can be an asset, not a handicap. The Kwakwaka'wakw example, again, did not suggest that beings responsible for salmon had punished either child or parents or community, but rather had given them a gift, albeit a sensitive one that had to be entrained. The Iban example is arguably similar. In any event, whether these gifted individuals distracted people in their society from real, transformative change or did nothing to help other disabled people, their experiences complicate assumptions about how power flows and from whom. More in-depth accounts of disability, like the ones we outline here, are one way of addressing this limited interpretation by offering alternative ways of being with disability. As such, they serve as a necessary complement to more transnational approaches that place disability within conversations and critiques of global inequality and injustice.

Following the global turn in studies of debilitation and disability (see Erevelles 2011; Puar 2017), it is not only important to note that God or witches cause impairment, that idiocy has a cosmological etiology, in other words. Rather, how this is dealt with by individual actors unravels in a broader set of moral and social relations with colonial and post-colonial governance. We would suggest that no comparative account of disability is adequate should it fail to consider either of these alternative poles of political and relational extension, debilitated or exemplary personhood. If a critical account of debility ignored what was said by different Iban about relating with exemplary persons, for instance, then the resulting complication of relationality and personhood would be lost as well. Returning to the Kwakwaka'wakw example once more, one cannot claim that chiefs had a monopoly on power if many people believed that such power relied on relations with other-than-human beings. If, as claimed by Ruyle (1973), chiefly beneficence through potlatch was premised in part on elite monopolistic control of supernatural power (and its manifestation in excess fish), then once again the fact that some twin and 'crippled' children were 'randomly' born with connections to fish would seem to complicate what purely secular theories of power have assumed.

Disability theorists have done much to challenge normative assumptions about the kinds of things we desire and the futures we imagine possible, but 
they tend to operate with an agreed-upon secular imaginary that automatically excludes any and all believers in more-than-human beings. Such an approach excludes not only the religious faithful in late-liberal societies, but also black and indigenous people of color around the world whose social relations and obligations are central to their lives and to their conceptions of ability/disability.

\section{Conclusion}

In order to conceptualize the othering of minority minds and bodies (Block et al. 2001), disability studies have made some, albeit limited, use of cross-cultural comparison, demonstrating the mutual benefit of such an exchange. Developing Douglas's (1966) classic argument about cultural dirt, for instance, Rosemarie Garland-Thomson (1997: 33) finds various "cultural patterns that show how the disability category operates" across the world. Both scholars argue that these patterns include (1) reducing to an absolute, (2) eliminating, (3) avoiding through segregation, (4) labeling as dangerous or risky, and (5) transforming through ritual. In keeping with this list, disability may be considered absolutely distinct as a category when it is reduced to an individual and medical condition.

This reduction partly accounts for the fact that, first, disability has not entered broader consideration in anthropology (Ginsburg and Rapp 2013). The fact that who is deemed to be 'normal' and 'abnormal' varies historically and culturally is also obscured, as are broader systems of debilitation that mete out misfortune unevenly (Erevelles 2011). Second, disability may go entirely unmentioned or unelaborated upon, as can occur when evidence of it in the ethnographic record is forgotten or ignored (as we have shown). Third, disability may be silenced because, for instance, people with disabilities are often misrepresented as passive victims or beneficiaries of social discipline, as if they live only marked, segregated existences apart, rather than being integral to society or, at the very least, virtually central to a systemic ableism that may afflict us all. Fourth, disabled existences may be made to appear unlivable or unworthy of life, thereby justifying oppressive regimes and neo-colonial projects that seek to end the risk of disabilities. Finally, disability may be integrated into ritual practice, with connections to other-than-human and non-secular forces, for example. Garland-Thomson is not concerned, nor are we, as to whether these options are truly universal, exhaustive, or mutually exclusive. In fact, we have shown how they can contribute to one another in various ways. But we would argue that the last example, that of ritual or metaphysical meaningfulness, is one of the least developed examples on Garland-Thomson's list, although it was very important for Douglas.

For many anthropologists, disability might appear only briefly, fleetingly, with what we have called the virtual presence of disability, in the form of a 
normative warning or prohibition (if you do or fail to do X, then $\mathrm{Y}$ will result). In other ways, anthropologists and other human scientists deploy disability themselves to make a point. Searching for reference to disability in the ethnographic record, as we have, it becomes clear that the words 'blind', 'deaf', 'lame', and 'mute' are most commonly used as ways of talking about failures and errors, limitations and barriers ("fell on deaf ears," "crippling realization," "blind to the possibility," "lame response"). This willingness to use disability rhetorically, as a narrative prosthesis (Mitchell and Snyder 2000), but not to engage with disability as a human reality reflects deep-seated ableist assumptions, even and especially if scholars only think to call attention to ideologically normative bodies and minds in comparative analyses of humanity. ${ }^{4}$

To take disability, debility, and empowerment or potency seriously, as we have suggested, does not just add new forms of difference to the exploration of alterity. Some of these conditions call into question the very assumptions, the 'normal' preconditions, that are thought to make ethnographic fieldwork possible (see Günel et al. 2020). These ideal preconditions include, especially, general similarities of mental and physical form that allow difference to be recognized, mapped, and shared, and the unspoken influence that this may have on marked conceptions of (in)ability in turn. An anthropology that takes disability seriously is one within which the differential embodiment of ethnography is brought to the surface, including experiences of bodily misfortune, their own and that of others, all of which change as a result of the relational and political negotiation of the fieldwork encounter. This would not only make ethnography something more inclusive-in terms of who conducts such research and who is involved in projects as interlocutors-but also would provide more of a cultural repository for truly transnational and cross-cultural conceptions of disability to emerge.

Uncovering accounts of what is thought about disability from the ethnographic and historical record would ideally lead to more evidence about the actual lives, experiences, and voices of people living as disabled, as debilitated, and as empowered in various ways. In the brief examples we have discussed, however, many of those people were not given a voice (e.g., Kwakwaka'wakw twins and 'cripples'). Challenging assumptions about disability also means destabilizing dominant ways of knowing in general, that is, what counts as epidemiologically relevant in the first place, as a way to resist "the often objectifying realms of 'research' about disabled people” (Snyder and Mitchell 2006: 4). Social science research about disabled 'populations' (as opposed to 'persons') is much like (supposedly) bygone freak shows of the early twentieth century, whereby "that which is created as off-limits in public spaces garners the capital of the unfamiliar" (ibid.: 158). Whether filmic or ethnographic, representations of disability can take part in how "disability becomes a commodity that has both use value as well as exchange value" (Erevelles 2011: 29) in the circuits of transnational capitalism. This can be seen in how persons with disabilities 
from poorer countries are enrolled in biomedical trials and testing to the benefit of global elites, or how neurodiversity can become commodified as a resource in the right circumstances (Grinker 2020).

The value of a comparative and critical anthropology of disability, like the one we have outlined here, is that it offers more radical alternatives to what being with disability means than might otherwise come from accounts originating primarily from late-liberal societies, no matter how experimental and inventive the latter appear to be. If critical disability studies have some value to anthropological approaches to comparison and difference, as we argue, then the ethnographic record also provides a relatively untapped resource or cultural repository of ways of living and being with disability. More specifically, a comparative and critical study of disability can show approaches to being with disability that directly run counter to widespread and hegemonic ideas.

Of course, disability is no simple thing to introduce into comparative discussion, yet it is arguably no more complex than forms of difference like race, class, gender, and sexuality. ${ }^{5}$ More to the point, these forms of difference historically intersect with one another. And, unfortunately, some of the most recognized attempts to collect cross-cultural accounts of disability are not concerned with the transnational networks within and through which comparison always unfolds and with which it always partakes. Disability does not simply exist in the world as an isolable object to study or compare, nor does archival research about disability (or anything) merely exist in that sense-they both are part of the world in relation to broader social and political conditions that give value and power to representations, especially those presented as objective 'facts'. We submit that attending to and extending the relationality and politics of disability is a productive way of doing so, as it can potentially address limitations in both contemporary anthropology and disability studies, to the benefit of both.

\section{Acknowledgments}

We wish to thank the rest of the class on "Disability in Society and Culture," taught in the autumn of 2019 at Binghamton University, as well as Britt Halvorson for helpful suggestions on an earlier draft of this article. 
Joshua Reno is a Professor of Anthropology at Binghamton University. He is the author of Waste Away: Working and Living with a North American Landfill (2016) and Military Waste: The Unexpected Consequences of Permanent War Readiness (2019). Most recently, with Britt Halvorson he co-wrote Imagining the Heartland: White Supremacy and the American Midwest (forthcoming in 2022), which argues that there is an unexamined affinity between whiteness, Midwestness, and Americanness, anchored in shared ordinary and homogenized qualities. E-mail: jreno@binghamton.edu

Kaitlyn Hart is an undergraduate student at Binghamton University. She will be graduating in May 2022 with a BA in Political Science and English and a minor in Anthropology. E-mail: khart1@binghamton.edu

Amy Mendelson is an undergraduate student at Binghamton University. In May 2022, she will be graduating with a BA in Anthropology. E-mail: amendel4@ binghamton.edu

Felicia Molzon is a first-year PhD student at the City University of New York's Graduate Center. Their research focuses on the relationships between intellectual disability, political agency, and social imaginaries. E-mail: fmolzon@ gradcenter.cuny.edu

\section{Notes}

1. Our critical examination of a troubled and troubling ethnographic record is inspired by Dave's (2011: 26) summary of the "tentative embrace of absence" of queer lives in the historical record that some scholars of South Asia employ, working between the known and unknowable.

2. At the time of Boas and Hunt's work, the term 'cripple' was not necessarily considered derogatory, although it gradually became recognized as such, as do many words for disability when they are recruited to do more than label difference in the service of compulsory able-bodiedness. Crip theorists have provocatively reappropriated this term to combat ableism (McRuer 2006, 2018).

3. For a similar reason, Severin Fowles (2013) prefers 'doings' to refer to Pueblo practices that otherwise might be termed 'religious rites' or 'rituals', which are categories that make it seem as if certain doings are more 'spiritual' and others more practical or political, in keeping with broadly secular categories (see also Mahmood 2005).

4. Standard ethnographic practice potentially further compounds local ableist assumptions about the incompetence of others. Familiar ethnographic fieldwork stories normally end when competence and acceptance are gained. 
5. As Strathern ([1991] 2004) maintains, complexity is always relative to shifting approaches to analogy and scale.

\section{References}

Ablon, Joan. 1984. Little People in America: The Social Dimensions of Dwarfism. New York: Praeger.

Ablon, Joan. 1988. Living with Difference: Families with Dwarf Children. New York: Praeger.

Ablon, Joan. 1999. Living with Genetic Disorder: The Impact of Neurofibromatosis 1. Westport, CT: Greenwood Press.

Block, Pamela, Fabricio Balcazar, and Christopher Keys. 2001. "From Pathology to Power: Rethinking Race, Poverty, and Disability.” Journal of Disability Policy Studies 12 (1): 18-27.

Boas, Franz. 1932. “Current Beliefs of the Kwakiutl Indians.” Journal of American Folklore 45 (176): 177-260.

Boas, Franz, and George Hunt. 1921. Ethnology of the Kwakiutl: Based on Data Collected by George Hunt (No. 1). Washington, DC: US Government Printing Office.

Bolton, Jason Coráñez. 2016. “Crip Native Woman: The Hispanic American Philippines and the Postcolonial Disability Cultures of US Empire.” PhD diss., University of Michigan.

Cepek, Michael L. 2016. "There Might be Blood: Oil, Humility, and the Cosmopolitics of a Cofán Petro-Being." American Ethnologist 43 (4): 623-635.

Codere, Helen, ed. 1966. Kwakiutl Ethnography. Chicago: University of Chicago Press.

Connell, Raewyn. 2011. "Southern Bodies and Disability: Re-thinking Concepts." Third World Quarterly 32 (8): 1369-1381.

Dave, Naisargi N. 2011. "Abundance and Loss: Queer Intimacies in South Asia." Feminist Studies 37 (1): 14-27.

Devlieger, Patrick, Beatriz Miranda-Galarza, Steven E. Brown, and Megan Strickfaden, eds. 2016. Rethinking Disability: World Perspectives in Culture and Society. Antwerp: Garant.

Dorsey, George Amos, James R. Murie, and Alexander Spoehr. 1940. "Notes on Skidi Pawnee Society.” In Anthropological Series 27: 65-119. Chicago: Field Museum Press. http://ehrafworldcultures.yale.edu/document?id = nq18-005.

Douglas, Mary. 1966. Purity and Danger: An Analysis of Concepts of Pollution and Taboo. New York: Routledge.

Edgerton, Robert B. 1967. The Cloak of Competence: Stigma in the Lives of the Mentally Retarded. Berkeley: University of California Press.

Edgerton, Robert B. 1970. "Mental Retardation in Non-Western Societies: Toward a Cross-Cultural Perspective on Incompetence.” In Social-Cultural Aspects of Mental Retardation, ed. H. C. Hayward, 532-559. New York: Appleton-Century-Crofts. 
Engelke, Matthew. 2015. "Secular Shadows: African, Immanent, Post-Colonial." Critical Research on Religion 3 (1): 86-100.

Erevelles, Nirmala. 2011. Disability and Difference in Global Contexts: Enabling a Transformative Body Politic. New York: Palgrave Macmillan.

Ford, Clellan S. (1941) 1968. Smoke from Their Fires: The Life of a Kwakiutl Chief. Prospect Heights, IL: Waveland Press.

Fowles, Severin M. 2013. An Archaeology of Doings: Secularism and the Study of Pueblo Religion. Santa Fe, NM: School for Advanced Research Press.

Friedner, Michele Ilana. 2018. "Vessel of God/Access to God: American Sign Language Interpreting in American Evangelical Churches.” American Anthropologist 120 (4): 659-670.

Garland-Thomson, Rosemarie. 1997. Extraordinary Bodies: Figuring Physical Disability in American Culture and Literature. New York: Columbia University Press.

Ginsburg, Faye, and Rayna Rapp. 2013. "Disability Worlds.” Annual Review of Anthropology 42: 53-68.

Ginsburg, Faye, and Rayna Rapp. 2020. "Disability/Anthropology: Rethinking the Parameters of the Human: An Introduction to Supplement 21." Current Anthropology 61 (S21): S4-S15.

Graeber, David. 2001. Toward an Anthropological Theory of Value: The False Coin of Our Own Dreams. New York: Palgrave.

Graham, Penelope. 1987. Iban Shamanism: An Analysis of the Ethnographic Literature. Canberra: ANU Press.

Grech, Shaun. 2015. “Decolonising Eurocentric Disability Studies: Why Colonialism Matters in the Disability and Global South Debate.” Social Identities 21 (1): 6-21.

Grinker, Roy Richard. 2020. “Autism, 'Stigma,' Disability: A Shifting Historical Terrain.” Current Anthropology 61 (S21): S55-S67.

Günel, Gökçe, Saiba Varma, and Chika Watanabe. 2020. "A Manifesto for Patchwork Ethnography.” Member Voices, Fieldsights, 9 June. https://culanth.org/ fieldsights/a-manifesto-for-patchwork-ethnography.

Hanks, Jane R., and L. M. Hanks, Jr. 1948. "The Physically Handicapped in Certain Non-Occidental Societies.” Journal of Social Issues 4 (4): 11-20.

Humphrey, Caroline. 2007. "Exemplars and Rules: Aspects of the Discourse of Moralities in Mongolia." In The Ethnography of Moralities, ed. Signe Howell, 25-47. London: Routledge.

Hutcheon, Emily J., and Bonnie Lashewicz. 2020. “Tracing and Troubling Continuities between Ableism and Colonialism in Canada." Disability \& Society 35 (5): 695-714.

Ingstad, Benedicte and Susan Reynolds Whyte, eds. 1995. Disability and Culture. Berkeley: University of California Press.

Jaffee, Laura Jordan. 2016. “Disrupting Global Disability Frameworks: SettlerColonialism and the Geopolitics of Disability in Palestine/Israel.” Disability \& Society 31 (1): 116-130.

Jensen, Erik. 1974. The Iban and Their Religion. Oxford: Clarendon Press. 
Kafer, Alison. 2013. Feminist, Queer, Crip. Bloomington: Indiana University Press. Klinken, Adriaan van. 2019. Kenyan, Christian, Queer: Religion, LGBT Activism, and Arts of Resistance in Africa. University Park: Pennsylvania State University Press.

Klotz, Jani. 2004. "Sociocultural Study of Intellectual Disability: Moving Beyond Labelling and Social Constructionist Perspectives.” British Journal of Learning Disabilities 32 (2): 93-104.

Laidlaw, James. 2013. The Subject of Virtue: An Anthropology of Ethics and Freedom. New York: Cambridge University Press.

Lamb, Sarah. 2000. White Saris and Sweet Mangoes: Aging, Gender, and Body in North India. Berkeley: University of California Press.

Livingston, Julie. 2005. Debility and the Moral Imagination in Botswana. Bloomington: Indiana University Press.

Mahmood, Saba. 2005. Politics of Piety: The Islamic Revival and the Feminist Subject. Princeton, NJ: Princeton University Press.

Masco, Joseph. 1996. “Competitive Displays: Negotiating Genealogical Rights to the Potlatch at the American Museum of Natural History." American Anthropologist 98 (4): 837-852.

McRuer, Robert. 2006. Crip Theory: Cultural Signs of Queerness and Disability. New York: NYU Press.

McRuer, Robert. 2018. Crip Times: Disability, Globalization, and Resistance. New York: NYU Press.

Mitchell, David T., and Sharon L. Snyder. 1997. The Body and Physical Difference: Discourses of Disability. Ann Arbor: University of Michigan Press.

Mitchell, David T., and Sharon L. Snyder. 2000. Narrative Prosthesis: Disability and the Dependencies of Discourse. Ann Arbor: University of Michigan Press.

Puar, Jasbir K. 2017. The Right to Maim: Debility, Capacity, Disability. Durham, NC: Duke University Press.

Reid-Cunningham, Allison Ruby. 2009. "Anthropological Theories of Disability.” Journal of Human Behavior in the Social Environment 19 (1): 99-111.

Robbins, Joel. 2015. "Ritual, Value, and Example: On the Perfection of Cultural Representations.” Journal of the Royal Anthropological Institute 21 (S1): 18-29.

Ruyle, Eugene E. 1973. "Slavery, Surplus, and Stratification on the Northwest Coast: The Ethnoenergetics of an Incipient Stratification System." Current Anthropology 14 (5): 603-631.

Schebesta, Paul, and Frieda Schütze. 1954. "Negritos of Asia; Vol. 2, Ethnography of the Negritos: Half-Vol. 1, Economy and Sociology." Studia Instituti Anthropos. Wien-Mödling: St.-Gabriel-Verlag. http://ehrafworldcultures.yale.edu/ document?id = an07-001.

Sewid, James. 1971. Guests Never Leave Hungry: The Autobiography of James Sewid, a Kwakiutl Indian. Ed. James P. Spradley. New Haven, CT: Yale University Press.

Shakespeare, Tom. 2017. Disability: The Basics. New York: Routledge.

Shildrick, Margrit. 2001. Embodying the Monster: Encounters with the Vulnerable Self. Thousand Oaks, CA: Sage. 
Shuttleworth, Russell P., and Devva Kasnitz. 2004. "Stigma, Community, Ethnography: Joan Ablon's Contribution to the Anthropology of Impairment-Disability.” Medical Anthropology Quarterly 18 (2): 139-161.

Snyder, Sharon L., and David T. Mitchell. 2006. Cultural Locations of Disability. Chicago: University of Chicago Press.

Speck, Frank G. (1909) 2004. Ethnology of the Yuchi Indians. Lincoln: University of Nebraska Press.

Stiker, Henri-Jacques. 1999. A History of Disability. Trans. William Sayers. Ann Arbor: University of Michigan Press.

Strathern, Marilyn. (1991) 2004. Partial Connections. Walnut Creek, CA: AltaMira Press.

Titchkosky, Tanya. 2011. The Question of Access: Disability, Space, Meaning. Toronto: University of Toronto Press.

Torrance, Robert M. 1994. The Spiritual Quest: Transcendence in Myth, Religion, and Science. Berkeley: University of California Press.

Vizenor, Gerald. 1994. Manifest Manners: Postindian Warriors of Survivance. Middletown, CT: Wesleyan University Press.

Walens, Stanley. 1981. Feasting with Cannibals: An Essay on Kwakiutl Cosmology. Princeton, NJ: Princeton University Press.

Webster, Gloria Cranmer. 1991. “The Contemporary Potlatch.” In Chiefly Feasts: The Enduring Kwakiutl Potlatch, ed. Aldona Jonaitis, 227-248. Seattle: University of Washington Press.

Woodill, Gary. 1994. “The Social Semiotics of Disability.” In Disability Is Not Measles: New Research Paradigms in Disability, ed. Marsha H. Rioux and Michael Bach, 201-226. Ontario: Roeher Institute. 